\title{
ROLE OF ZINC DEFICIENCY IN THE SUSCEPTIBILITY TO DELAYED POLYNEUROPATHY IN ORGANOPHOSPHORUS INTOXICATED PATIENTS IN ZAGAZIG UNIVERSITY HOSPITALS, ZAGAZIG, EGYPT
}

\author{
Marwa Ahmed Abass", Manar Hamed Arafa*, Yara Mohamed Elfakharany*, \\ Hebatallah Husseini Atteia** \\ *Department of Forensic Medicine \&Clinical Toxicology, ${ }^{* *}$ Department of Biochemistry, \\ Faculty of Pharmacy, Zagazig University, Egypt \\ *** Department of Pharmaceutical Chemistry, Faculty of Pharmacy, Tabuk University, Tabuk, \\ Kingdom Saudi Arabia
}

\begin{abstract}
Organophosphorus pesticides are widely used as insecticides in agriculture both in developed and developing countries in spite of reported potential toxicity. They induce neurotoxic effects either upon acute or chronic exposure. It was found previously that zinc $(\mathrm{Zn})$ supplementation exerted a neuroprotective effect against organophosphorus pesticide-induced neurodegenerative disorders in experimental animals. This study therefore, aimed to investigate the possible association between serum zinc level and organophosphorus-induced delayed polyneuropathy. Fifty acute organophosphorus poisoned cases admitted to Zagazig University Hospitals from February to August 2016 were enrolled in this study. Another Forty six healthy individuals (age- and sex-matched) served as a control group. Both groups were investigated for serum lipid peroxidation product (malondialdehyde: MDA) and total antioxidant capacity (TAC) levels as well as lymphocytic neuropathy target esterase (NTE) and plasma acetylcholinesterase (AChE). Then, they were followed up for 4 weeks to assess the development of delayed polyneuropathy (diagnosed clinically and confirmed by motor and sensory conduction studies). Serum levels of Zn, MDA and TAC as well as lymphocytic NTE and plasma AChE were measured for those developed organophosphorus delayed polyneuropathy. Organophosphorus intoxication has resulted in a significant elevation in the levels of MDA, suggesting oxidative stress. On the other hand, TAC levels as well as measured lymphocytic NTE and plasma AChE activities were found to be significantly reduced in the intoxicated group. However, at the end of the follow up period, 7 cases developed delayed polyneuropathy; 5 of them were $\mathrm{Zn}$ deficient while the rest were with normal $\mathrm{Zn}$ level. Cases with delayed polyneuropthy showed also a significant increase in lipid peroxidation along with impairment of estrases activities compared to cases on admission. Furthermore, serum $\mathrm{Zn}$ level showed a significant positive correlation with TAC, AChE, NTE and a negative correlation with MDA, where serum zinc level seems to be the strongest determinants for the prediction of delayed polyneuropathy. Thus, we conclude that $\mathrm{Zn}$ deficiency has a potential role in organophosphorus induced delayed polyneuropathy. This may be due to its involvement in the activity of antioxidant enzymes. However, further future large scale studies are needed to clarify the exact mechanism by which $\mathrm{Zn}$ deficiency mediated neurotoxicity upon organophosphorus induced polyneuropathy.
\end{abstract}

Keywords: AChE; MDA; NTE; Organophosphorus; Polyneuropathy; TAC; Zinc 


\section{INTRODUCTION}

Organophosphorus-induced delayed polyneuropathy (OPIDN) is a rare toxicity resulted from exposure to certain organophosphorus (OP) pesticides. It is characterized by distal axonal degeneration of both the peripheral and central nervous systems. It is commonly occurring 1-4 weeks after acute toxicity (Lotti and Moretto, 2005). Early symptoms include sharp, cramp-like pains in the calves (Jokanovic et al. 2002). Less severe cases exhibit a characteristic highstepping gait (Karalliedde et al., 2006). The initial muscle weakness gives rise to a clumsy and shuffling gait. The most disabling feature is the paralysis of the legs. In severe cases, quadriplegia with foot and wrist drop is seen, as well as mild pyramidal signs (Jokanovic et al., 2002). The neuropathic findings begin peripherally and proceed proximately. Lower extremity paresthesias may appear with a "stocking-glove" distribution and progress to weakness, ataxia, depression of deep tendon reflexes, and paralysis with occasional progression to the arms and hands (Chatterjee and Sharma, 2003). Human and experimental data indicate that recovery is usually complete in young patients. The electrophysiological changes include reduced amplitude of the compound muscle potential, increased distal latencies and normal or slightly reduced nerve conduction velocities. The progression of the disease, usually over a few days, may lead to non-excitability of the nerve with electromyographical signs of denervation. Nerve biopsies have been performed in a few cases and showed axonal degeneration with secondary demyelination (Nand et al., 2007).
Neuropathy target esterase (NTE) is thought to be the target of OPIDN initiation. The ratio of inhibitory powers for acetylcholinesterase (AChE) and NTE represents the crucial mark for the development of OP-induced peripheral neuropathy and its etiology. Animal studies revealed that $\mathrm{OP}$ insecticides with cholinergic toxicity like chlorpyrifos, dichlorvos, isofenphos, methamidophos, mipafox, trichlorfon, trichlornat, phosphamidon/mevinphos and by certain carbamates, have much higher potential to result in OPIDN (Sogorb et al., 2016). Zinc (Zn), a key constituent of more than 300 mammalian enzymes and many transcription factors has proved its protective potential in various models of animal pesticides toxicity. $\mathrm{Zn}$ has been proven to have hepato-protective potential against chlorpyrifos toxicity (Malhotra and Dhawan, 2014). This study therefore, aimed to investigate the possible association between serum $\mathrm{Zn}$ level and organophosphorus -induced delayed polyneuropathy.

\section{SUBJECTS \& METHODS} STUDY POPULATION

Ninety six consecutive organophosphorus poisoned cases admitted to Zagazig University Hospitals from February to August 2016, they were suffering from cholinergic crises. Only fifty patients were enrolled in the study according to the inclusion criteria. They suffered from nausea, vomiting, diarrhoea, salivation, urination, sweating, copious secretions, bradycardia, hypotension, miosis, wheeze, chest crepitation, weakness, fasciculation, cramps, paralysis, coma and respiratory failure. They were treated with airway control, decontamination, $\mathrm{O} 2$ therapy, and 
administration of antidotes; atropine and pralidoxime and other routine treatment. They were 21 females and 39 males with age range (12-57 years). Inclusion criteria include single moderate to severe organophosphorus poisoning or cases with delayed presentation (>12 hour post ingestion). Exclusion criteria were history of diabetes mellitus, thyroid disease, chronic low back pain, acquired or hereditary polyneuropathy. Forty six healthy individuals (age- and sex-matched) served as a control group. Informed consents from patients and approval letter were obtained from the Ethical Committee for Research (Institutional Review Board 'IRB'), Faculty of Medicine, Zagazig University.

Case and control groups were assessed for serum lipid peroxidation product (malondialdehyde: MDA), and total antioxidant capacity (TAC) levels, as well as lymphocytic neuropathy target esterase (NTE) and plasma AChE. Following discharge from hospitals cases were instructed to seek poison control unit (PCU) if they complain from one or more of the followings; tingling, numbness, muscle pain, and/or walking difficulty. Cases also instructed to visit PCU every week for a period of 4 weeks for development of polyneuropathy. Cases were examined for gait assessment, deep tendon reflexes, muscle strength, and vibration, pin, light touch, and thermal sensitivities. Motor and Sensory conduction studies were done to confirm the diagnosis of polyneuropathy. Cases were tested by the Viking Quest Nicolet electromyography apparatus. Nerve conduction (motor and sensory) studies were conducted on median, ulnar, sural, peroneal and tibial nerves. Cases which developed polyneuropathy were subjected to in depth history taking and routine investigations including whole blood count, liver, kidney functions, electrolyte profiles, creatine kinase enzyme and erythrocyte sedimentation rate to exclude other causes of polyneuropathy. Blood samples were collected from those with normal routine investigations to assess serum $\mathrm{Zn}$, MDA, TAC levels, lymphocytic NTE and AChE activities.

\section{METHODS}

Plasma acetylcholinesterase (AChE) activity was determined colorimetrically according to the method of Ellman et al. (1961). The reaction was done twice for each sample in the same time. Briefly, $4 \mathrm{ml}$ solution containing $4 \mathrm{mM}$ tris buffer $(\mathrm{pH}=7.4), 40 \mathrm{mM} \mathrm{MgCl}$, $0.1 \mathrm{mM} \times 10^{-4} \mathrm{M}$ DTNB (colouring reagent), and $0.2 \mathrm{mM} \times 10^{-4} \mathrm{M}$ of $\mathrm{S}$ butyrylthiocholine iodide (substrate) were pre-incubated at $37^{\circ} \mathrm{C}$ for $10 \mathrm{~min}$ for coupling. $20 \mu \mathrm{l}$ of plasma samples was added into each tube of the aforementioned substrate solution. The mixture was vortexed and absorbances of produced yellow colour were read spectrophotometrically at 1 min interval for $3 \mathrm{~min}$ at $412 \mathrm{~nm}$. Blank was run parallel to each sample without addition of substrate. Activity was expressed as $\mathrm{U} / \mathrm{l}$.

Lymphocytes were isolated by centrifuging in a Ficoll-Verografin density gradient. Lymphocytic NTE activity was measured according to the method of Johnson (1977) by a reaction depends on the enzymatic cleavage of phenylvalerate to phenol, which is subjected to a colour reaction that can be measured spectrophotometrically. 50 $\mu l$ of the lymphocytic suspension was pipetted into a plastic tube. The tube was filled with deionised water to $5 \mathrm{ml}$ and allowed to stand for $5 \mathrm{~min} .1 \mathrm{ml}$ of 
the lymphocytic haemolysate was filled into 4 sealable test-tubes with a capacity of (2 sample blanks and 2 samples). Samples were incubated with 0.5 Tris EDTA buffer, $0.5 \mathrm{ml}$ of 2 organophosphates, paraoxon and mipafox working solutions at $37^{\circ} \mathrm{C}$ for $20 \mathrm{~min}$ in shaking bath. The reaction mixture was further incubated with $2 \mathrm{ml}$ stop I and $2 \mathrm{ml}$ substrate solutions at $37^{\circ} \mathrm{C}$ for $60 \mathrm{~min}$ in shaking bath and then with $2 \mathrm{ml}$ stop I and $2 \mathrm{ml}$ colour solutions at room temperature for 15 min. The absolute NTE activity was calculated from the difference between the phenylvalerate concentrations in the lymphocyte samples containing only paraoxon and in those samples containing also mipafox. Finally, absorbance was determined at $492 \mathrm{~nm}$ using deionised water as a blank. The absorbance of samples was read in duplicate.

Zinc ( $\mathrm{Zn})$ concentration was determined in $1 \mathrm{ml}$ serum sample after digestion for $24 \mathrm{~h}$ with conc nitric acid and hydrochloric acid (5:1) (Luterotti et al., 2015). Samples were then filtered, diluted with deionized water and analyzed for $\mathrm{Zn}$ using atomic absorption flame emission spectrophotometery at wavelength 213.9 $\mathrm{nm}$.

Serum malondialdehyde (MDA was determined by measuring thiobarbituric reactive species using the method of Yagi (1998) in which the thiobarbituric acid-reactive substances react with thiobarbituric acid to produce a red colored complex with peak absorbance at $532 \mathrm{~nm}$.

Serum total antioxidant capacity (TAC) was determined using commercially available kit (Biodiagnostic, Dokki, Giza, Egypt) by the reaction of antioxidants in the sample with a defined amount of exogenously provide hydrogen peroxide $\left(\mathrm{H}_{2} \mathrm{O}_{2}\right)$. The antioxidants eliminate a certain amount of the provided $\mathrm{H}_{2} \mathrm{O}_{2}$. The residual $\mathrm{H}_{2} \mathrm{O}_{2}$ is determined colorimetrically by an enzymatic reaction which involves the conversion of $3, \quad 5, \quad$ dichloro-2-hydroxy benzensulphonate to a colored product (Koracevic et al., 2001). STATISTICAL ANALYSIS

The collected data were computerized and statistically analyzed using Statistical Package for the Social Sciences (SPSS) programme version 15. Quantitative data were summarized as mean + standard deviation $(\mathrm{X}+\mathrm{SD})$. Qualitative data were summarized as percentage. Test of significance for qualitative data was $\mathrm{X}^{2}$ (chi-square) test. Test of significance for quantitative data was done using student $t$ test for comparison between groups' means. Pearson correlation test was used to evaluate the association between two variables. Logistic regression analysis was performed to identify the independent predictors of variables. The significance level was considered at $\mathrm{p}$ value $<0.05$

\section{RESULTS}

\section{A - Admission Results}

The results of this study showed highly significant decreases $\quad(\mathrm{P}<0.001)$ in plasma ACh E, lymphocytic NTE, and TAC in patients at time of admission when compared with controls. On other hand as regard serum MDA, at admission there was highly significant increase $(\mathrm{P}<0.001)$ when compared with controls $\begin{array}{lllll}\text { results } & \text { (Table } & \mathbf{1} & \boldsymbol{\&} & \text { Fig.1). }\end{array}$ 
Table (1): Statistical analysis student t-test of plasma AChE, lymphocyte NTE, serum TCA, serum MDA in the controls and cases.

\begin{tabular}{|c|c|c|c|c|}
\hline parameters & $\begin{array}{c}\text { Controls } \\
\mathrm{N}=46 \\
\end{array}$ & $\begin{array}{l}\text { Cases } \\
\mathbf{N}=\mathbf{5 0} \\
\end{array}$ & $\mathbf{t}$ & $\mathbf{p}$ \\
\hline $\begin{array}{c}\text { Plasma ACh E (U/l) } \\
\text { X } \pm \text { SD } \\
\text { Range }\end{array}$ & $\begin{array}{c}7875.8 \pm 2030.9 \\
4946-12901\end{array}$ & $\begin{array}{c}2163.2 \pm 1066.2 \\
899-5000\end{array}$ & 17.45 & $<0.001 *$ \\
\hline $\begin{array}{c}\text { Lymphocyte } \mathrm{NTE}(\mathrm{mU} / \mathrm{g} \text { protein) } \\
\mathrm{X} \pm \mathrm{SD} \\
\text { Range }\end{array}$ & $\begin{array}{l}12.9 \pm 2.6 \\
6.9-16.5\end{array}$ & $\begin{array}{l}5.8 \pm 1.2 \\
3.2-8.5\end{array}$ & 17 & $<0.001 *$ \\
\hline $\begin{array}{c}\mathrm{TAC}(\mathrm{nM} / \mathrm{l}) \\
\mathrm{X} \pm \mathrm{SD} \\
\text { Range }\end{array}$ & $\begin{array}{c}1.63 \pm 0.4 \\
1.098-2.501\end{array}$ & $\begin{array}{c}0.8 \pm 0.16 \\
0.322-0.975\end{array}$ & 14.5 & $<0.001 *$ \\
\hline 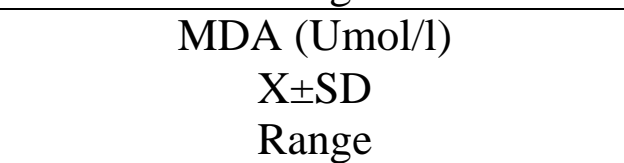 & $\begin{array}{c}0.67 \pm 0.07 \\
0.56-0.8\end{array}$ & $\begin{array}{l}1.07 \pm 0.13 \\
0.84-1.26\end{array}$ & 18.5 & $<0.001 *$ \\
\hline
\end{tabular}

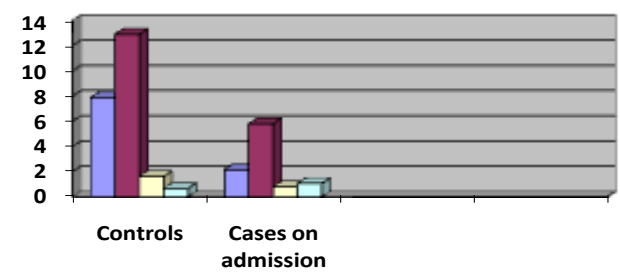

Figure (1): Comparison between cases and controls on admission

\section{B- Follow up Results:}

At the end of the follow up period, 7 cases out of 46 cases completed the study developed delayed polyneuropathy. The most common complaints were muscular pain, difficult walking, tingling and numbness. Clinical examination revealed bilateral symmetrical weakness in distal muscles of the lower limbs, sluggish deep tendon reflex and sensory loss in hands and feet. Serum zinc level for these cases showed that $5(71.4 \%)$ of them were $\mathrm{Zn}$ deficient (range: 5.1$8.7 \mathrm{Umol} / \mathrm{l}$ ) while the rest were with normal Zn level (range: 14.3-15.7
Umol/1). Results of motor and sensory conduction study revealed mixed sensory motor polyneuropathy (Table 2). Cases with delayed polyneuropthy showed highly significant decreases $(\mathrm{P}<0.001)$ in serum zinc level, lymphocytic NTE, and TAC compared to controls. On other hand regarding serum MDA, there was highly significant increase $(\mathrm{P}<$ 0.001) when compared with control results while plasma $\mathrm{AChE}$ showed no significant difference in comparison with control results (Table $3 \& \quad$ Fig. 2 ). 
Table (2): Statistical analysis by student t-test of (NCV), sensory NC and SNAP amplitude in control and patient groups

\begin{tabular}{|c|c|c|c|c|}
\hline $\begin{array}{c}\text { MOTOR NERVE } \\
\text { CONDUCTION }\end{array}$ & $\begin{array}{c}\text { Cases with } \\
\text { polyneuropathy } \\
\mathbf{N = 7}\end{array}$ & $\begin{array}{c}\text { Controls } \\
\mathbf{N = 4 6}\end{array}$ & $\mathbf{t}$ & $\mathbf{P}$ \\
\hline NCV (m/s) & $48 \pm 2.2$ & $39.2 \pm 0.8$ & 26.4 & $<0.001^{*}$ \\
Tibial Nerve & $44 \pm 1.5$ & $22 \pm 2.2$ & 56.7 & $<0.001^{*}$ \\
Peroneal Nerve & $50 \pm 3.0$ & $46.1 \pm 1.6$ & 8.2 & $<0.001^{*}$ \\
Median Nerve & $56 \pm 2.5$ & $50.3 \pm 0.2$ & 16.0 & $<0.001^{*}$ \\
Ulnar Nerve & & & & \\
SENSORY NERVE & & & & \\
CONDUCTION & $6 \pm 0.3$ & $5.8 \pm 0.1$ & 4.4 & $<0.001^{*}$ \\
SNAP amplitude ( $\mu$ V) & $10 \pm 0.5$ & $28.1 \pm 0.8$ & 131.1 & $<0.001^{*}$ \\
Sural Nerve & $15 \pm 0.2$ & $29.0 \pm 0.5$ & 177.2 & $<0.001^{*}$ \\
Ulnar Nerve & & & & \\
Median Nerve & & & & \\
\hline
\end{tabular}

NCV = Nerve conduction velocity; SNAP $=$ Sensory nerve action potential $*=$ high significance

Table (3): Statistical analysis student t-test of serum zinc levels, serum TAC, serum MDA, plasma AChE and lymphocyte NTE in control and cases with polyneuropathy

\begin{tabular}{|c|c|c|c|c|}
\hline parameters & $\begin{array}{l}\text { Controls } \\
\mathrm{N}=46\end{array}$ & $\begin{array}{c}\text { Cases with } \\
\text { polyneuropathy } \\
\mathrm{N}=7\end{array}$ & $\mathbf{t}$ & $\mathbf{p}$ \\
\hline $\begin{array}{l}\text { Serum Zinc level (Umol/I) } \\
\text { X } \pm \text { SD } \\
\text { Range }\end{array}$ & $\begin{array}{l}23.4 \pm 5.8 \\
13.4-34.5\end{array}$ & $\begin{array}{l}9.0 \pm 4.3 \\
5.1-15.7\end{array}$ & 6.29 & $<0.001 *$ \\
\hline $\begin{array}{l}\text { TAC }(\mathrm{nM} / \mathrm{l}) \\
\mathrm{X} \pm \text { SD } \\
\text { Range }\end{array}$ & $\begin{array}{l}1.63 \pm 0.4 \\
1.098-2.501\end{array}$ & $\begin{array}{l}0.85 \pm 0.25 \\
0.322-1.1 \\
\end{array}$ & 4.99 & $<0.001 *$ \\
\hline $\begin{array}{l}\text { MDA }(\text { Umol/l }) \\
\text { X } \pm \text { SD } \\
\text { Range } \\
\end{array}$ & $\begin{array}{l}0.67 \pm 0.07 \\
0.56-0.8\end{array}$ & $\begin{array}{l}0.85 \pm 0.13 \\
0.68-0.99\end{array}$ & 5.58 & $<0.001 *$ \\
\hline $\begin{array}{l}\text { Plasma ACh E (U/l) } \\
\text { X } \pm \text { SD } \\
\text { Range }\end{array}$ & $\begin{array}{l}7875.8 \pm 2030.9 \\
4946-12901\end{array}$ & $\begin{array}{l}8062.4 \pm 970 \\
6894-9500 \\
\end{array}$ & 0.237 & $0.8132^{\mathrm{NS}}$ \\
\hline $\begin{array}{l}\text { Lymphocyte NTE }(\mathrm{mU} / \mathrm{g} \\
\text { protein) } \\
\text { X } \pm \text { SD } \\
\text { Range }\end{array}$ & $\begin{array}{l}12.9 \pm 2.6 \\
6.9-16.5\end{array}$ & $\begin{array}{l}4.6 \pm 1.0 \\
3.6-6.4\end{array}$ & 8.295 & $<0.001 *$ \\
\hline
\end{tabular}

$$
* \text { = high significance } \quad \text { NS }=\text { non significance }
$$



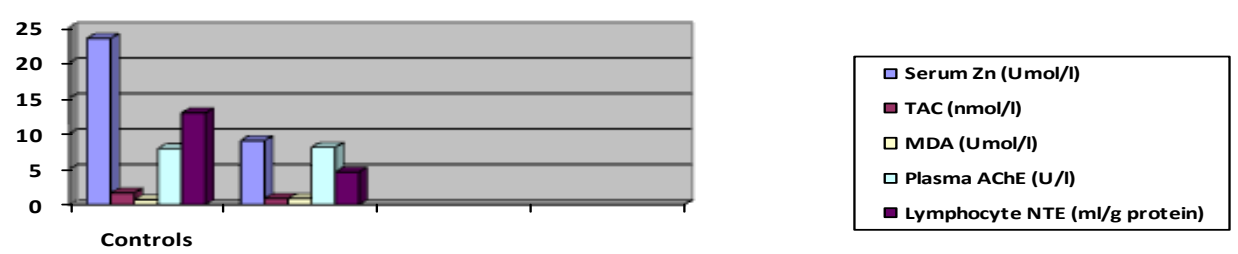

Figure (2): Comparison between cases developed delayed polyneuropathy after the

follow up period and control

\section{C-Correlation Results:}

When correlation was done between serum $\mathrm{Zn}$ level and other tested parameters there was a significant positive correlation with TAC, AChE, NTE and a negative correlation with MDA $(p<0.001)$. When we introduce all significant variables to multiple regression analysis (the model), the variables that persisted significant (the strongest significant) in the model was serum $\mathrm{Zn}$ level. Therefore, serum $\mathrm{Zn}$ level seems to be significant determinant factors for the prediction of delayed polyneuropthy (Tables 4\&5, Fig 2).

Table (4): Statistical analysis Pearson correlation coefficient between serum zinc level and, serum TCA, serum MDA, Plasma AChE and lymphocyte NTE

\begin{tabular}{|c|c|c|}
\hline Parameters & r & p \\
\hline TAC (nM/l) & 0.44 & $<0.001^{*}$ \\
\hline MDA (Umol/I) & -0.41 & $<0.001^{*}$ \\
\hline Plasma Ch E (U/l) & 0.38 & $<0.001^{*}$ \\
\hline Lymphocyte NTE (mU/g protein) & 0.31 & $<0.001^{*}$ \\
\hline
\end{tabular}

$*$ = high significance
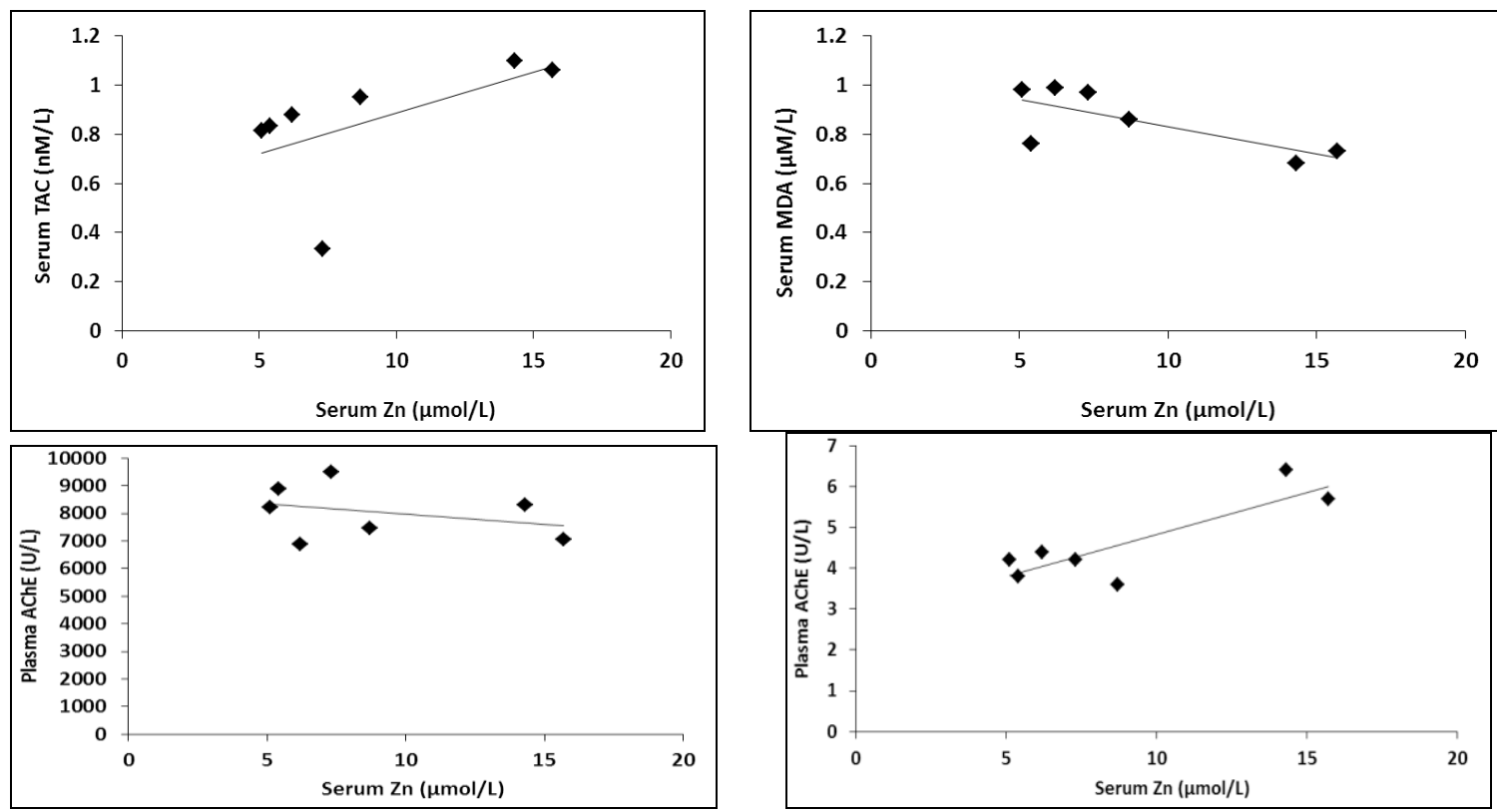

Figure (3): Correlations between serum $\mathrm{Zn}$ level and other parameters in the study group by the end of the follow up period. 
Table (5): Multiple regression analysis for prediction of delayed polyneuropathy

\begin{tabular}{|c|c|c|}
\hline Parameters & $\boldsymbol{\beta} \pm$ SE & $\mathbf{P}$ \\
\hline Serum zinc $(\mathrm{Umol} / \mathrm{l})$ & $0.01 \pm 0.002$ & $<0.001^{*}$ \\
\hline \multicolumn{2}{|c|}{$*$ high significance }
\end{tabular}

\section{DISCUSSION}

Poisoning with organophosphates $(\mathrm{OP})$ is a global problem (Gunnell et al., 2007). They are widely used for pest control and they have been used as a suicidal agent as they are readily available and accessible in developing countries (Cha et al., 2014).

Organophosphorus compounds have three distinct neurotoxic actions. The primary action is the irreversible inhibition of acetylcholinesterase, resulting in the accumulation of acetylcholine and subsequent overstimulation of the nicotinic and muscarinic acetylcholine receptors leading to cholinergic effects. Second, a delayed onset of ataxia, accompanied by a Wallerian-type degeneration of the axon and myelin in the most distal portion of the longest tracts in both the central and peripheral nervous systems that is known as organophosphorus esterinduced delayed neurotoxicity (OPIND). A third is organophosphorus esterinduced chronic neurotoxicity, characterized by long-term, chronic neurotoxicity symptoms in individuals resulting from acute exposure to high doses that cause acute cholinergic toxicity, or from long-term, low-level, subclinical doses of these chemicals (Abou-Donia, 2005).

Although the incidence of (OPIDN) is considered low (Richardson, 2005), it is still of great concern, because humans are highly susceptible and the disease cannot be stopped once it is initiated (Lotti, 1987 and Cole et al., 1998).

Several studies suggested different mechanisms of OPIDN. Although the inhibition of AChE or Neuropathy target esterase (NTE) were frequently suggested but it was not proven (Abou-Donia, 2005). On the other hand, the role of essential trace elements as promising and efficient preventive prophylactic agents without any toxicity and side effects in attenuating the adverse hazards caused by pesticides, have been reported by various scientists. Moreover, Zinc was proved to have a hepato-protective role during various toxic states including pesticide toxicity (Malhotra and Dhawan, 2014)

So the aim of this study was to investigate the possible association between serum zinc level and organophosphorus-induced delayed polyneuropathy through evaluation of serum levels of $\mathrm{Zn}$, MDA and TAC as well as lymphocytic NTE and plasma AChE for those developed organophosphorus delayed neuropathy.

The current study was performed on 50 cases with acute organophosphorus poisoning. Their results on admission revealed significant decreases in plasma AChE, lymphocytic NTE, TAC with a significant increase in MDA when compared with control subjects. These results are in accordance with Pope et al. (2005) and Reiner et al. (2007) who stated that the toxicity of organophosphorus is attributed to their ability to inhibit acetylcholinesterase which is a class of enzymes that catalyzes the hydrolysis of the neurotransmitting agent acetylcholine (ACh). The inhibition of AChE and related esterases has been clearly demonstrated to be the result of an actual chemical reaction between the enzyme and the organophosphate. The 
phosphorylated enzyme is no longer capable of affecting the hydrolysis of $\mathrm{ACh}$; this results in a buildup of the neurotransmitter at a nerve synapse or neuromuscular junction

Hussain (2010) demonstrated that apart from inhibition of cholinesterase and presence of cholinergic effects, oxidative stress has been reported by many authors as one of the adverse effects in poisoning by OP in both humans and animals. Oxidative stress induced by organophosphate leads to disturbances in the function of different organs and tissues. In addition, Mashali et al. (2005) concluded that organophosphorus poisoning induces oxidative stress leading to generation of free radicals, as evidenced by the elevated MDA levels, and alterations in antioxidants and scavengers of oxygen free radicals.

These results support our work where we found a significant increase in MDA level, as a biomarker for lipid peroxidation, and a significant decrease In TAC in OP intoxicated subjects when compared with control group were detected.

The inhibition in the activity of lymphocytic NTE in the current study made our cases at a high risk for developing OPIDN. Clothier and Johnson (1980), Williams (1983), Moretto et al. (1987), Lotti and Moretto (2005) and Read et al. (2010) suggested that the initial mechanism associated with development of OPIDN is phosphorylation and subsequent aging of NTE enzyme. These events lead to progressive deficit of retrograde axonal transport in the nervous system. Moreover, the current study included moderate to severe poisoned cases and those with delayed presentation that make them at higher risk for developing
OPIDN. It is well established that the risk for esterases enzyme aging is more likely in severe cases and in late presenters Clothier and Johnson (1980).

In the present study, cases developed OPIDN have mixed sensory motor polyneuropathy with predominating motor affection. OPIDN begins with sensory loss in hands and feet, but exclusively sensory neuropathy is not a feature in humans. Motor alterations such as slowed conduction and, eventually, bilateral and symmetrical weakness progressing to flaccidity of the lower and upper extremities were described in the literature (Gallo and Lawryk, 1991 \& Ecobichon, 1994).

Moreover, cases developed OPIDN in the present study showed a significant decrease in NTE with significant improvement of plasma AChE and oxidative stress indicators (MDA, TAC). NTE inhibition may be responsible for the development of OPIDN. These results are in accordance with Abou-Donia (2005) who stated that the involvement of $\mathrm{AChE}$ and butyrylcholinesterase in the mechanisms of OPIDN have been eliminated.

Moreover, Makhaevaa et al. (2007) and Mundu et al. (2016) stated that inhibition of the enzyme neuropathy target esterase (NTE) by Organophosphorous compounds with ageing of the NTE-OP conjugate is responsible for the delayed polyneuropathy in some of the patients. Also, Makhaevaa et al. (2016) reported that inhibition and aging of $>70 \%$ of neuropathy target e sterase (NTE) in neural tissue initiates OPIDN and that inactivation of acetylcholinesterase (AChE) is not involved.

On the contrary, Winrow et al., 2003 and Abou-Donia (2005) reported that the hypothesis of inhibition and ageing of the 
neurotoxicity target esterase (NTE), by organophosphorus compounds, results in OPIDN has not been proven. Their most convincing evidence against this hypothesis is the recent finding that NTEknockout mice are sensitive to the development of OPIDN, indicating that this enzyme is not solely involved in the mechanisms of OPIDN.

In addition, Pomeroy-Black et al. (2007) stated that elucidation of the pathophysiology and mechanism of OPIDN, as well as the assessment of OP compounds for their neuropathic potential, has been hampered by a lack of knowledge concerning the physiological function of NTE and deficiencies in available models, either in vivo or in vitro.

A previous study showed that $\mathrm{Zn}$ supplementation to chlorpyrifos-treated animals nearly normalized lipid peroxidation and induced free radical generation in cerebrum. This was associated with a significant improvement in the levels of antioxidants including reduced glutathione, and GST enzymatic activity of in both cerebrum as well as cerebellum alnong with improvement was in the behavior of chlorpyrifos-treated animals upon $\mathrm{Zn}$ supplementation. Therefore, $\mathrm{Zn}$ seems to have a potential to act as a neuroprotectant against pesticide-induced neurodegenerative and behavioral disorders (Malhotra et al., 2011). Such neuroprotective effect of $\mathrm{Zn}$ could be attributed to being a cofactor in several antioxidant enzymes. $\mathrm{Zn}$ is an essential trace element that regulates a large number of metabolic processes in the brain (Singla and Dhawan, 2017). It is one of the most abundant essential minerals. It is present in the structure of many proteins, like enzymes and transcription factors and modulates the function of other proteins, including receptors, enzymes and proteins involved in cell signalling. Zinc is a key micronutrient in the physiology of the nervous system, participating in the modulation of synaptic transmission, regulation of neuronal cell oxidant production, regulation of signalling cascades, neural cell proliferation, cell survival, and neuronal differentiation (Adamo and Oteiza, 2010).

These studies along with studies questioned the role of NTE in OPIDN make the rational for us to investigate the role of $\mathrm{Zn}$ in development of delayed polyneuropathy in our cases. Moreover, using lymphocyte NTE in humans as a biomarker of OPIDN has many restrictions. Lymphocytes are heterogeneous, have variability in the expression of NTE and not well correlated with inhibition of central NTE activity (lotti et al., 1984) and it is not available in clinical labs of hospitals to be ordered routinely. However, serum zinc level is cheap and available in many clinical laboratories and can be used as a biomarker for prediction of OPIDN.

Serum zinc levels of our cases with OPIDN revealed a significant decrease when compared with controls. Furthermore, there was a positive correlation between seum $\mathrm{Zn}$ level and NTE and TAC. Serum Zn level was negatively correlated with MDA. Moreover Zinc was found to be the strongest determinant factor for the prediction of delayed polyneuropathy.

The essential role of zinc is demonstrated by the deleterious effects of zinc deficiency and by the link between zinc regulatory dysfunction and the pathophysiology of various disease states, including neurodegeneration. Zinc acts as a cofactor for an estimated 3,000 human proteins, representing $10 \%$ of the 
genome, and has a well-established role in regulation of gene expression through metalresponsive transcription-factor-1 (MTF1) genome, and has a wellestablished role in regulation of gene expression through metalresponsive transcription-factor-1 (MTF1) (Taylor et al., 2012). Also, Zinc is an integral part of the transcription factor Miz1 (Mycinteracting zinc finger 1) which is a known regulator of the cell functions in the peripheral nervous system. Deletion of the Miz1 domain in Schwann cells is well known to induce an acute neuropathy as shown by previous studies (Sanz-Moreno et al., 2015\& Kerosuo et al., 2008\& Adhikary et al., 2003).

Szewczyk, 2013 stated that deficiency, rather than an excess of zinc leads to an increased risk for the development of neurological disorders. Indeed, zinc deficiency has been shown to affect neurogenesis and increase neuronal apoptosis, which can lead to learning and memory deficits. Altered zinc homeostasis is also suggested as a risk factor for depression, Alzheimer'sdisease, aging, and other neurodegenerative disorders.

Zinc has a role as a second messenger involved in a regulating various pathways often by inhibiting protein tyrosine phosphatases (PTPs) (Yamashita et al., 2004, Hogstrand et al., 2009 and Sensi et al, 2009).

Abou-Donia (2005) hypothesized that the increased aberrant protein kinase mediated phosphorylation of cytoskeletal proteins could result in the destabilization of microtubules and neurofilaments, leading to their aggregation and deregulation in the axon. He stated that imbalance in calcium homeostasis lead to the activation of calcium activated neutral protease and increase in the calcium/calmodulin dependent protein kinases. These events contribute to abnormal phosphorylation of cytoskeletal proteins and protein digestion in the terminal axon that can proceed similarly to Wallerian-type

Moreover, Beyersmann \& Haase (2001) stated that zinc is demonstrated to modulate intracellular signaling cascades such as mitogen-activated protein kinases, protein kinase $\mathrm{C}$ and $\mathrm{Ca} 2+/$ calmodulin activated protein kinase II, therefore participating in cell proliferation and differentiation. In addition, Finamore et al. (2008) stated that zinc deficiency affects the amounts of junctional and cytoskeleton proteins and phosphorylation level in terminal axons involved in OPIDN.

Also, Adamo and Oteiza (2010) concluded that Zinc deficiency in neuronal cells culture in developing nervous system causes the activation of the initial events in the pathway, which occurs as a consequence of zinc deficiency-induced increase in oxidant production

Zinc deficiency can cause oxidative stress as evidenced by its association to increased levels of cell oxidants (Ho \& Ames, 2002 and Mackenzie et al., 2006), altered activity and concentration of antioxidant enzymes (Oteiza et al., 1996 and Virgili et al., 1999), decreased glutathione levels (Bagchi et al., 1999), and tissue oxidative damage, including increased lipid, protein and DNA oxidation (Oteiza et al., 1995).

Moreover, it was found that the protective effect of zinc against diabetesinduced peripheral nerve damage is mediated through its stimulating effect on antioxidant synthesis and down regulation of oxidative stress (Liu et al., 2014). Also, several studies have demonstrated the protective effect of zinc 
on chlorpyrifos induced toxicity (Goel et al., 2005; Mansour and Mossa, 2009; Ambali et al., 2010, 2011) and malathion induced impairment in several antioxidant enzymes, showing to be a potential agent to be used against the prooxidative effects of OP compounds (Franco et al., 2009). These results can explain the strong correlation found in our study between deficiency of serum zinc level and oxidative stress marker.

\section{CONCLUSION}

Thus, we conclude that $\mathrm{Zn}$ deficiency has a potential role in organophosphorus induced delayed polyneuropathy. This may be due to its involvement in the activity of antioxidant and esterases enzymes.

\section{RECOMMENDATIONS}

In the light of the current results, it is recommended to add zinc supplements to treatment regimes of organophosphorus poisoning especially those having zinc deficiency on admission. Also, further future large scale studies are needed to clarify the exact mechanism by which $\mathrm{Zn}$ deficiency mediated neurotoxicity upon organophosphorus induced polyneuropathy.

\section{ACKNOWLEDGEMENT}

Great thanks and gratefulness to Prof. Dr. Ahmed Mohmed Ahmed Omar, Professor of Clinical Toxicology and director of Poisoning Clinical Unit, Zagazig University Hospitals for providing facilitation of the clinical part of the study.

\section{REFERENCES}

$\begin{array}{crr}\text { Abou-Donia, } & \text { M.B. } & (\mathbf{2 0 0 5}): \\ \text { Organophosphorus } & \text { ester-induced } \\ \text { chronic } & \text { neurotoxicity. }\end{array}$

Occupational Health Safety, 21(5): 408-432.

Adamo, A.M. 1 and Oteiza, P.I. (2010): Zinc deficiency and neurodevelopment: the case of neurons Biofactors, 36(2): 117-124.

Adhikary, S.; Peukert, K.; Karsunky, H.;Beuger, V.; Lutz, W.; Elsässer, H.P.; Möröy, T. and Eilers, M. (2003): Miz1 is required for early embryonic development during gastrulation. Molecular Cell Biology, 23(21):7648-57.

Ambali, S.F.; Abubakar, A.T.; Kawu, M.U.; Uchendu, C.; Shittu, M. and Salami, S.O. (2011): Biochemical alterations induced by subchronic chlorpyrifos exposure in Wistar rats: Ameliorative effect of zinc. Journal American Science, 7(9): 73-81.

Ambali, S.F.; Abubakar, A.T.; Shittu, M.; Yaqub, L.S.; Anafi, S.B. and Abdullahi, A. (2010): Chlorpyrifosinduced alteration of haematological parameters in Wistar rats: Ameliorative effect of zinc. Research Journal Environmental Toxicology, 4(2): 55-66.

Bagchi, D.; Vuchetich, P.J.; Bagchi, M.; Tran, M.X.; Krohn, R.L.; Ray, S.D. and Stohs, S.J.(1998): Protective effects of zinc salts on TPA-induced hepatic and brain lipid peroxidation, glutathione depletion, DNA damage and peritoneal macrophage activation in mice. General Pharmacology, 30:43-50.

Beyersmann, D., and Haase, H.(2001):Functions of zinc in signaling, proliferation and differentiation of mammalian cells. Biometals, 14, 331-341.

Cha, E. S.; Khang, Y-H. and Lee, W. J. (2014): Mortality from and incidence of pesticide poisoning in 
South Korea: Findings from National Death and Health Utilization Data between 2006 and 2010. PLoS One, 9(4): e95299.

Chatterjee, M. and Sharma, P.S. (2003): Unusual neurological complications in a case of organophosphate poisoning. Neurology India, 51:290-291.

Clothier, B. and Johnson, M.K. (1980): Reactivation and aging of NTE inhibited by a variety of OP esters. Biochemical Journal, 185(3):739-47.

Cole, D.C.; Carpio, F.; Julian, J. and Le'on, N. (1998): Assessment of peripheral nerve function in an Ecuadorian rural population exposed to pesticides. Journal Toxicology Environmental Health A, 55: 77- 91 .

Ecobichon, D. J. (1994): Organophosphorus insecticides, in Pesticides and Neurological Diseases (Ecobichon, D. J. and Joy, R. M., eds.), CRC Press, Boca Raton, FL, pp. 171-249.

Ellman, G.L.; Courtney, K.D.; Andres, V. Jr. and Feather-Stone, R.M. (1961): A new and rapid colorimetric determination of acetylcholinesterase activity. Biochemical Pharmacology, 7: 8895.

Finamore, A.; Massimi, M.; Devirgiliis, L. C. and Mengheri, E. (2008): Zinc Deficiency Induces Membrane Barrier Damage and Increases Neutrophil Transmigration in Caco-2 Cell. The Journal of Nutrition and Disease, 138(9):166470

Franco, J.L.; Thais, P.; Mattosb Jacó, J.; Rafael, T.; Brocardob, P.S.; Rodriguesb, A. L. S.; Lealb, R. B.; Farinab, M.; Marquesb, M. R.F.;
Bainyb, A.C.D and Dafrea, A.L. (2009): Zinc reverses malathioninduced impairment in antioxidant defenses. Toxicology Letters, 187:137-143

Gallo, M. and Lawryk, N. J. (1991): Organic phosphorus pesticides, in Handbook of Pesticide Toxicology (Hayes, W. J. and Laws, E. R., eds.), Academic Press, San Diego, pp. 917-1123.

Goel, A.; Dani, V. and Dhawan, D.K. (2005): Protective effects of zinc on lipid peroxidation, antioxidant enzymes and hepatic histoarchitecture in CPF-induced toxicity. Chemico-Biological Interaction, 156:131-140.

Gunnell, D.; Eddleston, M.; Phillips, M.R. and Konradsen, F. (2007): The global distribution of fatal pesticide self-poisoning: systematic review. BioMed Central Public Health, 7: 357.

Ho, E. and Ames, B.N. (2002): Low intracellular zinc induces oxidative DNA damage, disrupts p53, NFkappa B, and AP1 DNA binding, and affects DNA repair in a rat glioma cell line. Proceedings of the National Academy of Sciences, 99 (26): 16770-16775.

Hogstrand, C.; Kille, P.; Nicholson, R.I. and Taylor, K.M. (2009): Zinc transporters and cancer: a potential role for ZIP7 as a hub for tyrosine kinase activation. Trends in molecular medicine, 15:101-111.

Hussain A. L. (2010): Role of oxidative stress in organophosphate insecticide toxicity - Short review. Pesticide Biochemistry and Physiology, 98 (2): 145-150.

Johnson, M. K. (1977): Improved assay of neurotoxic esterase for screening organophosphates for delayed 
neurotoxicity potential. Archive Toxicology. 67:113-115.

Jokanovic, M.; Stukalov, P.V. and Kosanovic, M. (2002): Organophosphate induced delayed polyneuropathy. Current Drug Targets CNS Neurological Disorders, 1(6):593-602.

Karalliedde, L.; Baker, D. and Marrs, T.C. (2006): Organophosphateinduced intermediate syndrome: Aetiology and relationships with myopathy. Toxicological Reviews, 25(1):1-14.

Kerosuo, L.; Piltti, K.; Fox, H.; Angers-Loustau, A.; Häyry, V.; Eilers, M.; Sariola, H. and Wartiovaara, K. Myc (2008): increases self-renewal in neural progenitor cells through Miz-1. Journal Cell Science 1; 121 $(\mathrm{Pt}$ 23):3941-50.

Koracevic, D.; Koracevic, G.; Djordjevic, V.; Andrejevic, S. and Cosic, V. (2001): Method for the measurement of antioxidant activity in human fluids. Journal Clinical Pathology, 54(5): 356-361.

Liu, F.; Ma, F.; Kong, G.; Wu, K.; Deng, Z. and Wang, H. (2014): Zinc supplementation alleviates diabetic peripheral neuropathy by inhibiting oxidative stress and upregulating metallothionein in peripheral nerves of diabetic rats. Biological Trace Element Research, 158 (2):211-8.

Lotti, M. (1987): Organophosphateinduced delayed polyneuropathy in humans: perspectives for biomonitoring. Trends Pharmacological Science, 81: 17677.

Lotti, M. and Moretto, A. (2005): Organophosphate-induced delayed polyneuropathy. Toxicological Reviews, 24(1):37-49.

Lotti, M.; Becker, C.E. and Aminoff, M.J. (1984): Organophosphate polyneuropathy: pathogenesis and prevention. Neurology, 34(5):65862.

Luterotti, S.; Kordić, T.V. and Dodig, S. (2015): Contribution to diagnostics/prognostics of tuberculosis in children. I. New methods of assaying zinc and simultaneously copper and zinc in diluted sera by flame atomicabsorption spectrometry. Acta Pharmacology, 65(3):311-20.

Mackenzie, G.G.; Zago, M.P.; Erlejman, A.G.; Aimo, L.; Keen, C.L. and Oteiza, P.I. (2006): alpha-Lipoic acid and Nacetyl cysteine prevent zinc deficiencyinduced activation of NF-kappaB and AP-1 transcription factors in human neuroblastoma IMR-32 cells. Free Radical Research, 40:75-84.

Makhaevaa, G. F.; Malygin, V. V.; Strakhova, N. N.; Sigolaeva, L. V.; Sokolovskaya, L. G.; Eremenko, A. V.; Kurochkin, I. N. and Richardson, R. J. (2007): Biosensor assay of neuropathy target esterase in whole blood as a new approach to OPIDN risk assessment: review of progress. Human \& Experimental Toxicology, 26: $273-282$.

Makhaevaa, G. F.; Rudakovaa, E.V. and Sigolaevab L. V. (2016): Neuropathy target esterase in mouse wholeblood as a biomarker of exposure to neuropathic organophosphorus compounds. Journal Applied Toxicology, 36(11):1468-75.

Malhotra, A. and Dhawan D.K.(2014): Current view of zinc as 
a hepatoprotective agent in conditions of chlorpyrifos induced toxicity. Pesticide Biochemistry Physiology, 112:1-6

Malhotra, A.; Nair, P. and Dhawan, D.K. (2011): Efficacy of zinc as a nutritional supplement in ameliorating chlorpyrifos-induced neurotoxicity in rats. Journal Environmental Pathology Toxicology Oncology, 30(3):22533.

Mansour, S.A. and Mossa, A.H. (2009): Lipid peroxidation and oxidative stress in rat erythrocytes induced by chlorpyrifos and the protective effect of zinc. Pesticide Biochemistry Physiology, 93: 3439.

Mashali, A. A.; Nounou, H. A.; Sharara, G. M. and Abdel Aziz M. H. (2005): Role of oxidative stress and apoptosis in acute organophosphorus intoxicated patients. Journal of the Medical Research Institute, 26 (3): 255-263.

Moretto, A.; Lotti, M. and Sabri, M.I. (1987): Progressive deficit of retrograde axonal transport is associated with the pathogenesis of di-n-butyl dichlorvos axonopathy. Journal Neurochemistry, 49(5):1515-22.

Mundu, P.A.; Kumar, M.; Satapathy, R.P. and Mitra, J.K. (2016): Organophosphate Induced Delayed Neuropathy: A Case Report. International Journal of Contemporary Medical Research, 3(8):2289-2291.

Nand, N.; Aggarwal, H.K.; Bharti, K.and Chakrabarti, D. (2007): Organophosphate Induced Delayed Neuropathy. The Journal of the Association of Physicians of India, 55: 72-73.
Oteiza, P.I.; Olin, K.L.; Fraga, C.G. and Keen, C.L. (1995): Zinc deficiency causes oxidative damage to proteins, lipids and DNA in rat testes. Journal Nutrition, 125:823829.

Oteiza, P.L.; Olin, K.L.; Fraga, C.G. and Keen, C.L. (1996): Oxidant defense systems in testes from zincdeficient rats. Proceedings of the Society for Experimental Biology and Medicine, 213:85-91.

Pomeroy-Black M.J., Jortner, B.S., and Ehrich, M.F. (2007): Early effects of neuropathy inducing organophosphates on in vivo concentrations of three neurotrophins. Neurotoxicity Research, 11: 85-91.

Pope, C.; Karanth, S. and Liu, J. (2005): Pharmacology and toxicology of cholinesterase inhibitors: uses and misuses of a common mechanism of action. Environmental Toxicology Pharmacology, 19(3):433-46.

Read, D.J.; Li, Y. and Chao, M.V. (2010): Organophosphates induce distal axonal damage, but not brain edema, by inactivating neuropathy target esterase. Toxicology Applied Pharmacology, 245(1):108-15.

Reiner, E.; Radi, Z. and SimeonRudolf, V. (2007): Mechanisms of organophosphate toxicity and detoxication with emphasis on studies in Croatia. Archives of Industrial Hygiene and Toxicology, 58:329-338.

Richardson, R.J. (2005): Organophosphate poisoning, delayed neurotoxicity. In: Encyclopedia of toxicology, (Wexler P ed.) $2^{\text {nd }}$ ed., Vol. (3). Elsevier, Ltd., p.p. 302-306. 
Sanz-Moreno,

D.; Zankel,

H.; Kern,

D.; Niemann,

H.P.

(2015):

A.; Fuhrmann,

onset neuropathy with spontaneous clinical remission in mice lacking the POZ domain of the transcription factor Myc-interacting zinc finger protein 1 (Miz1) in Schwann cells. Journal Biology Chemistry, 290(2):727-43.

Sensi, S.L.; Paoletti, P.; Bush, A.I. and Sekler, I. (2009): Zinc in the physiology and pathology of the CNS. Nature reviews Neuroscience, 10:780-791.

Singla, N. and Dhawan, D.K. (2017): Zinc Improves Cognitive and Neuronal Dysfunction During Aluminium-Induced

Neurodegeneration. Molecular Neurobiology, 54(1):406-422.

Sogorb, M.A.; Pamies, D.; Estevan, C.; Estévez, J. and Vilanova, E. (2016): Roles of NTE protein and encoding gene in development and neurodevelopmental toxicity. Chemico- Biolioogical Interaction, 25; 259(Pt B):352-357.

Szewczyk, B. (2013): Zinc homeostasis and neurodegenerative disorders. Frontiers in Aging Neuroscience, 5(33):1-12.

Taylor, K.M.; Kille, P. and Hogstrand, C. (2012): Protein kinase CK2 opens the gate for zinc signaling. Cell Cycle, 15; 11(10): 1863-1864.
Virgili, F.; Canali, R.; Figus, E.; Vignolini, F.; Nobili, F. and Mengheri, E. (1999): Intestinal damage induced by zinc deficiency is associated with enhanced $\mathrm{CuZn}$ superoxide dismutase activity in rats: effect of dexamethasone or thyroxine treatment. Free Radical Biology Medicine, 26:1194-1201

Williams, D.G. (1983): Intramolecular group transfer is a characteristic of neurotoxic esterase and is independent of the tissue source of the enzyme. A comparison of the aging behaviour of di-isopropyl phosphorofluoridate-labelled proteins in brain, spinal cord, liver, kidney and spleen from hen and in human placenta. Biochemical Journal, 209(3):817-29.

Winrow, C.J.; Hemming, M.L.; Allen, D.A.; Quistad, G.B. Casida, J.E and Barlow, C. (2003): Loss of neuropathy target esterase in mice links organophosphate exposure to hyperactivity. Nature Genetics, 33: 477-485.

Yagi, K. (1998): Simple assay for the level of total lipid peroxides in serum or plasma. Methods Molecular Biology, 108:101-106.

Yamashita, S.; Miyagi, C.; Fukada, T.; Kagara, N.; Che, Y.S. and Hirano, T. (2004): Zinc transporter LIVI controls epithelialmesenchymal transition in zebrafish gastrula organizer. Nature, 429:298302. 


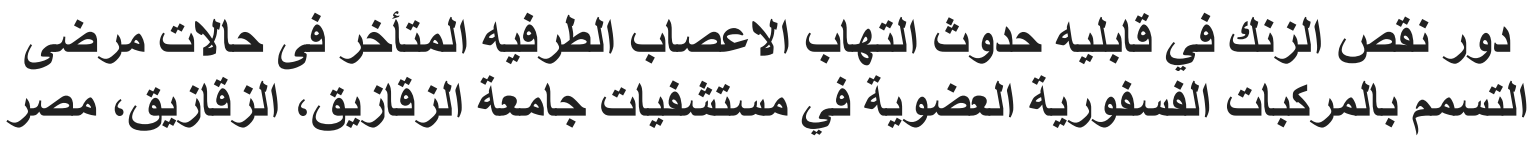

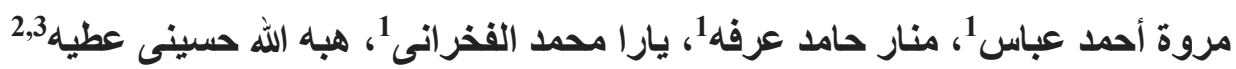

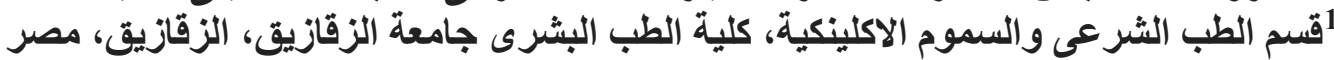

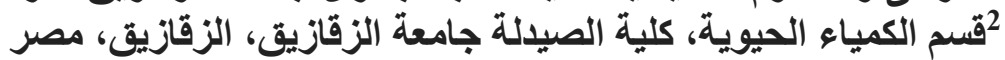

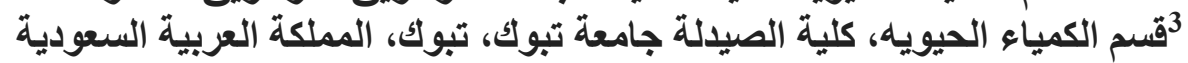

تستخدم المبيدات الفسفورية العضوية على نطاق واسع كمبيدات حشرية في الزراعة سواء في الدول المتقدمة

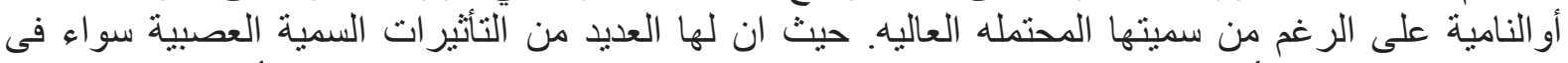

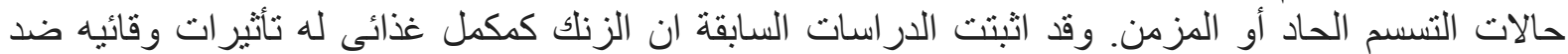

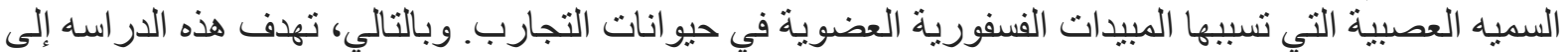

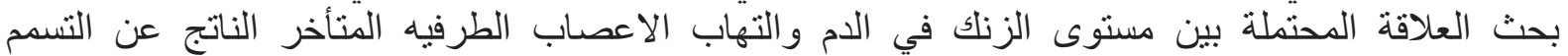

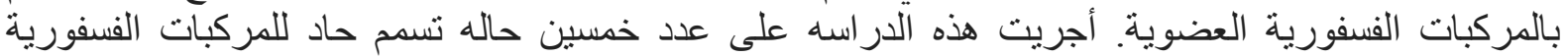
العضوية بمستشفيات جامعة الزقازيق فى الفترة من فبر اير إلى أغسطس 2016. ولى وعدد ستة وأربعين فرد دن دات

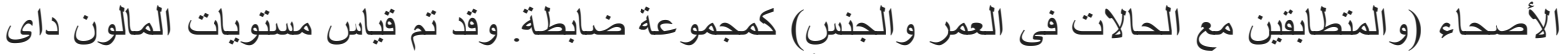

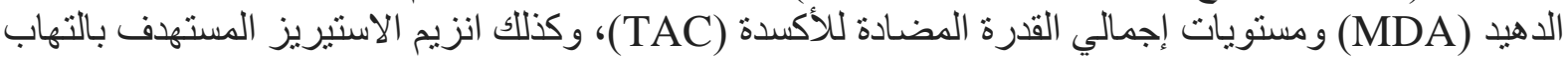

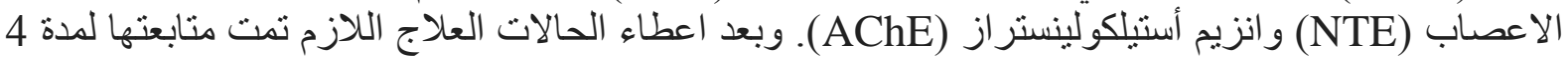

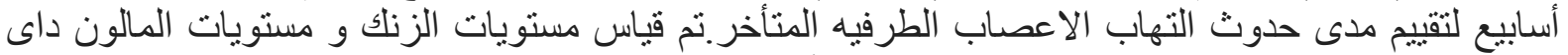

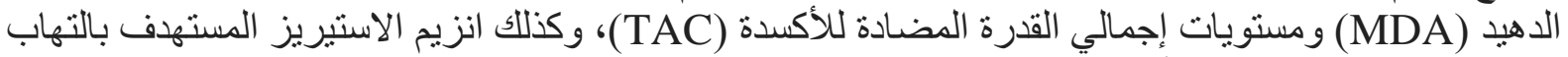

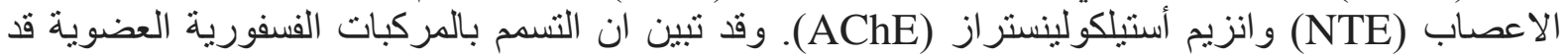
ادى الى ارتفاع كبير في مستويات (MDA)، مما يثير إلى حدوث الإنى الاجهاد التأكسدى وكذلك انخفاض في

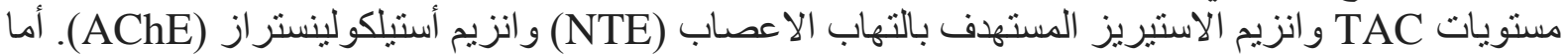

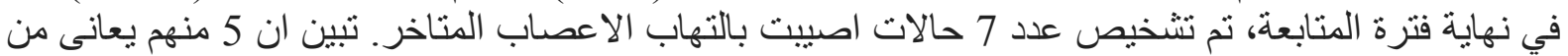
نقص في مستويات الزنك في حين كانت بقية الحالات بمستوى الزناتك الطبيعى. و أظهرت نتائج هذه الحالات زئات زيادة

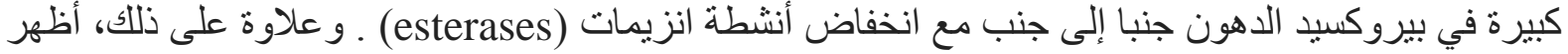

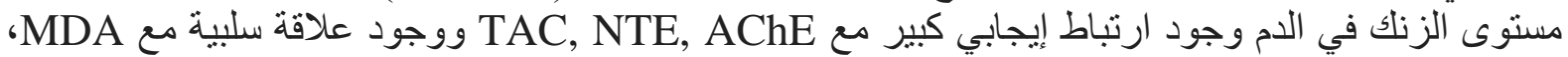

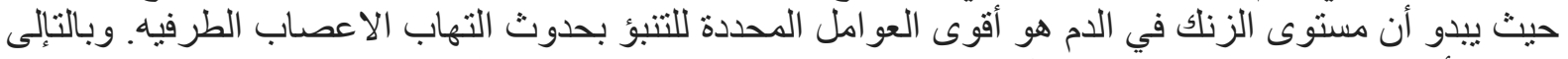

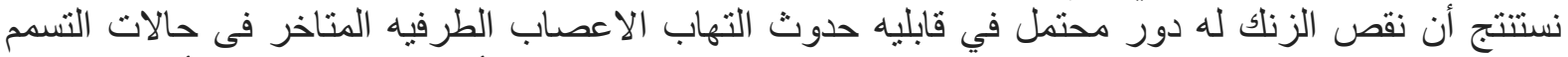

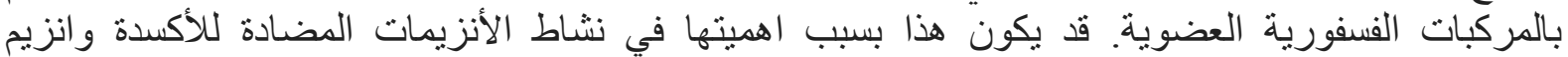

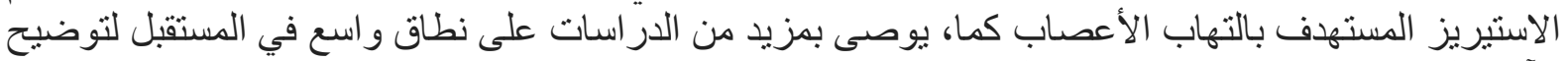

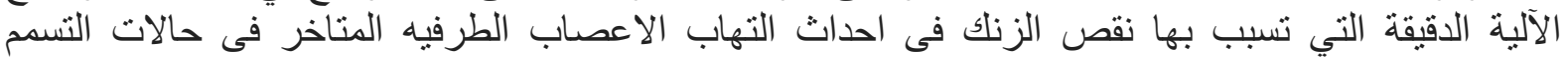
بالمركبات الفسفورية العضوية. 